\title{
The Role of Information in Contemporary Migration More Sources but Less Informed
}

\author{
Working paper
}

Elisabet González Martínez (egonzalezmartin@uoc.edu) Researcher at IN3

\section{Working Paper Series WP08-005}

Research programme: Immigration and the Information Society

Research programme director: Adela Ros Híjar

Submitted in: September 2008

Accepted in: October 2008

Published in: November 2008

\section{$\bullet$ UOC}

\section{IN3 Internet \\ interdisciplinary \\ Institute}

www.uoc.edu 
Internet Interdisciplinary Institute (IN3)

http://in3.uoc.edu/

Parc Mediterrani de la Tecnologia

Av. Canal Olímpic, s/n.

08860 Castelldefels

Barcelona (Spain)

Tel. 936735000

Universitat Oberta de Catalunya (UOC)

http://www.uoc.edu/

Av. Tibidabo, 39-43

08035 Barcelona

Spain

Tel. 932532300

(a)

SORERTIGHIS RESERNED
This report is subject to a Creative Commons Attribution-Noncommercial-NoDerivativeWorks 2.5 license. They may be copied, distributed and broadcast provided that the authors, the institution promoting them (IN3-UOC) and the Generalitat de Catalunya's support are cited. Commercial use and derivative works are not permitted. The full licence can be consulted on http://creativecommons.org/licenses/by-nc-nd/2.5/es/deed.en. 


\section{Table of contents}

Abstract

Introduction

1. The capacity to process information in the Information Society …………................. 6

1.1. Information travels across borders .............................................................................. 7

1.2. Moving in the Information Age .................................................................... 10

2. Changes in the information transmission .............................................................. 11

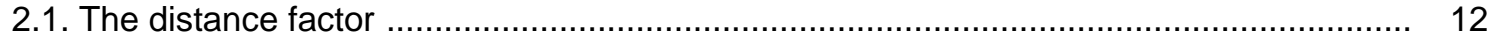

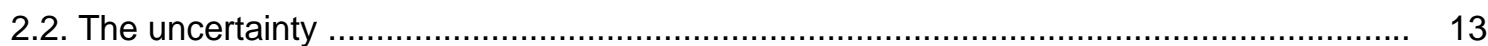

3. The information agents in contemporary migration .............................................. 15

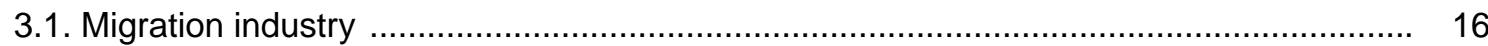

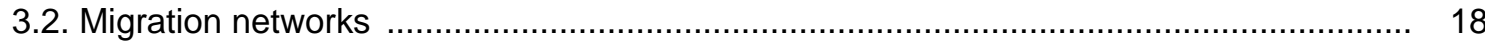

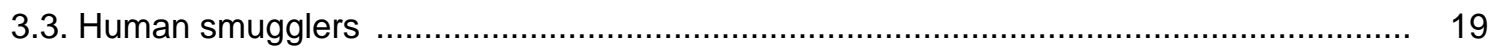

3.4. The official institutional framework ....................................................................... 19

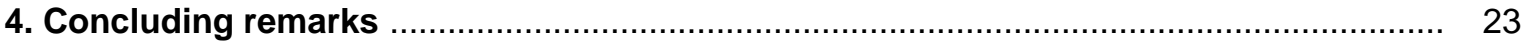

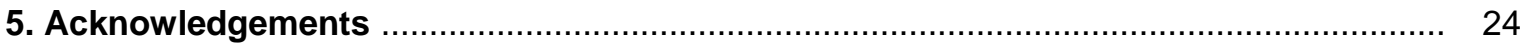

References 


\title{
The Role of Information in Contemporary Migration. More Sources but Less Informed
}

\author{
Elisabet González (egonzalezmartin@uoc.edu) \\ Researcher at IN3
}

\begin{abstract}
Contemporary international migration is embedded in a process of global interconnection defined by the transport and information and communication technologies revolutions. One of the consequences of this global interconnection is that migrants have more capacity to process information both before and after departure. These changes could have unexpected implications for contemporary migration as regards: migrants ability to make more informed decisions, the reduction of uncertainty in migration contexts, the blurring of the concept of distance, or the decision to migrate to more distant places. This research is important as the lack of knowledge concerning this issue could be contributing to the increasing gap between migration policy goals and outcomes. The role that information agents play in migration contexts may also be changing. In that scenario, migration policies to become more effective should take into consideration the greater capacity of migrants to process information and which information sources are relied upon. This paper will show that the equation "more information" equals "better informed" does not always work. Even in the Information Age, unreliable sources, false expectations, overinformation, and rumours, are still present in migration contexts. However, we defend the argument that these nondesired effects could be reduced by filling four requisites of reliable information: comprehensive, relevant, trusted, and updated.
\end{abstract}

\section{Keywords}

Migration, information, informed decisions, migration policies.

\section{Recommended citation:}

GONZÁLEZ, Elisabet (2008). The Role of Information in Contemporary Migration [online working paper]. UOC. (Working Paper Series; WP08-005). [Accessed: dd/mm/yy].

$<$ http://www.uoc.edu/in3/dt/eng/wp08005 gonzalez.pdf> 


\section{Introduction}

In reality, migration cannot take place without prior investment; it cannot occur in the absence of information (Guilmoto and Sandron, 2001: 139)

During the last two years, two episodes of migration arrivals into Spain have shown that contemporary migrations are incorporating into their dynamics a new, until now, unnoticed element: the capacity to process information, transcending barriers of time -at any moment - or space from any place. This capacity to process information could be directly affecting the decision to migrate, as is illustrated throughout the next two examples.

The first example refers to the Spanish "cayucos" crisis which occurred in $2006 .{ }^{1}$ Many migrants travelling by "cayucos" to Spain arrived with knowledge of where they had to go and/ or what they should say in order to stay. Some of those migrants knew that they arrived somebody would be waiting for them in a car to take them to other places in the peninsula where they could work irregularly (La Vanguardia, 2006). They also knew that by stating they were minors -even if they were not - they could not be repatriated to their country of origin. In any case, migrants and their families had information about how to react and when their loved ones had arrived to destination coasts. Referring to minors, a key player in charge of Equality of the regional government of the Canary Islands pointed out that, "Lots of [immigrant] minors arrive to Spain with mobile phones and significant amounts of money -up to one hundred euros- and their family members often call them to make sure they arrived o.k." (El País, 2006).

The second example is the reaction of a large number of Bolivians at the announcement of a required visa after April 2007. Until then, Bolivians did not need a visa to enter to Spain, just their passport and a flight ticket to return to Bolivia. The requirement was announced in September 2006 and since then hundreds of Bolivians tried to enter Spain. From October to December 2006, the arrivals of Bolivians to the Barajas Airport -the main Spanish airport-increased considerably. While in May the arrivals of Bolivians totalled 5.000, in October the number rose to 13.900, and in November there were 14.100 arrivals. In December, data from the national police labour union shows that arrivals were between 800 and 1.200 per day (El País, 2007).

The common element in both situations is the capacity that migrants had for processing information. In these two examples migrants knew what was happening before migrating with sufficient notice to react. These situations put information and communication opportunities at the core of the new migration reality.

For this paper, the key question is to investigate whether or not the amount of information that migrants have to decide about their migration project today is greater and more accurate than ever before, as a result of the capacity to better process information, thereby reducing the impact of distance and uncertainty on the decision to migrate.

Both examples illustrate that migrants are more informed than migration practitioners. If migration practitioners consider the capacity for processing information that migrants have, could it be easier and more efficient to manage the arrival of irregular migrants? At this stage, we defend the idea

${ }^{1}$ Cayuco is a Spanish term for 'raft' or 'canoe' and is commonly used to describe the vessel that some African migrants utilise in order to reach the Spanish coast. 
that knowing more about how information flows in migration contexts and what kind of information migrants have at the different stages of the process, could contribute to redefine policy measures managing migration flows, thus closing the gap between policy goals and policy outcomes. This debate is shared by those scholars as Castles (2004a) and Cornelius et al. (1994) who warn against the widening gap between the reality of migration and political responses, and the lack of relation between policy goals and policy outcomes. In Castles' words, "the more that states and supranational bodies do to restrict and manage migration, the less successful they seem to be" (Castles 2004a:205). In that sense, while policy goals tend to restrict international movement of people, the reality of migration is characterised by an increasing flow of migrants moving from one place to another (IOM 2005).

\section{The capacity to process information in the Information Society}

The increasing mismatch between policy goals and outcomes could be explained by a lack of knowledge of the contemporary migration reality, and more specifically by the lack of knowledge about the capacity to process information. If this is true, what are we referring to by the current migration reality? For our research purposes, by current migration reality we refer to the contextualization of migration flows embedded in the Information Society. In the Information Society, migrants are experiencing more capacity to process information both in origin and in destination countries. That capacity could have unexpected implications for contemporary migration as regards making more informed decisions, reducing uncertainty in migration contexts, blurring the concept of distance, or migrating to more distant places.

The Information Society is a set of global transformations that define the reality of contemporary societies. As Castells (1996) states the Information Society is the result of a technological paradigm that engenders an augmentation of human capacity of information processing and communication made possible by the revolutions in microelectronics-based in information and communication technology (ICT) such as computers and digital communications. These new information and communication tools imply three new opportunities to users. First, they provide more capacity for processing information. Second, they facilitate more capacity for interactions than ever before. And third, they offer more flexibility of actions than ever before moving from a traditional space of places to a dynamic space of flows (Castells, 1996).

Moving to the intersection between IS transformations and their impact on contemporary migration, Ros' work (2008) proposes four dimensions of the Information Society that are particularly relevant for migration.

First, information processing within migration networks is expanding -arriving to any place in the world cheaper and faster than ever before - and may introduce new patterns of communication frequency and simultaneity-. Second, the Information Society means high connectivity for migrant contexts is shaping a new space for interactions. Contemporary migration moves in a space of flows, leaving aside the more physical traditional space of places. Third, migrants may experience changes in their identity as they have the capacity to overcome time and space, even social and cultural constraints, independent of where they are. As Castells et al. (2007) state people may be able to set up their own connections bypassing traditional channels of communication of States and other institutions and organisations. This could be applied to migrants giving them more possibilities to communicate across borders without intermediaries. Fourth, the Information Society may empower those migrants that use information and communication tools, redistributing power in migration contexts. Connected migrants will be able to be present both in networks from origin 
countries but also in networks based in destination countries. They will be empowered to "act at distance" (Held et al. 1999).

Thus, better information processing, more capacity for interactions, and more flexibility of communications are central elements in contemporary migration contexts. However, this paper will focus on the first element, the increasing capacity for information processing in migration contexts. The aim is to know what kind of implications the capacity of information processing could have on contemporary migration. One could expect that as a result of the new tools of information and communication that the IS offers and the decreasing cost of international communications migrants could have access to wider information sources, making more informed decisions. However, this paper will show that the equation "more information" equals "better informed" does not always work. In this paper we will develop which elements should be taken into account when we refer to information processing in migration contexts.

Among the elements that one has to consider, we will explore the following two issues: the traditional uncertainty involved in the decision to migrate and the role that information agents play in migration contexts. Even in the Information Age, uncertainty, unreliable sources, false expectations, and overinformation, are still present in migration contexts. But, information in migration contexts could improve in quality by filling four requisites of reliable information: comprehensive, relevant, trusted, and updated. Contributing to a better description of the complexity of information processing in migration contexts, this paper seeks to fill the gap about these issues by offering an accurate analysis of how information flows in migration contexts in order to inform migration stakeholders. On the basis of a more comprehensive approach to contemporary migration -that recognises the importance of information processing -, it may be possible to design a more realistic migration policy, decreasing the widening gap between policy goals and policy outcomes.

Before pondering these questions, we will present some data in order to illustrate how information is reaching distinct geographical places faster and cheaper than ever before.

\subsection{Information travels across borders}

The Information Society, through the spreading of ICT, is offering new opportunities of information and communication to any place in the world. But, what makes these changes possible? How do potential migrants in different places of Africa and Latin America obtain accurate information before leaving? The communications revolution may provide an answer to these questions as it is promoting the penetration of ICT throughout the world. Communication technologies are reaching distant places making it possible to access information transcending the barriers of time and space. The spread of these transformations is accelerated by globalization and is affecting everywhere.

The global interconnection between distant places has also meant that information and communication technologies have arrived not only to developed societies but also to developing areas, most of which are origin countries. So, origin and destination migrant countries are embedded in these global transformations.

By looking at ICT data in origin countries it is possible to perceive a fast penetration of ICT in those countries.

Table 1. ICT's in origin countries 2000-2005 


\begin{tabular}{l|c|c|c|c|c|c|c|}
\cline { 2 - 8 } & $\begin{array}{c}\text { Operationa } \\
\text { I telephone } \\
\text { lines }\end{array}$ & $\begin{array}{c}\text { Dwellings } \\
\text { with Internet } \\
\text { [Per 100 } \\
\text { inhabitants] }\end{array}$ & $\begin{array}{c}\text { Broadband } \\
\text { Internet } \\
\text { [Per 100 } \\
\text { inhabitants] }\end{array}$ & $\begin{array}{c}\text { Personal } \\
\text { Computers } \\
\text { [Per 100 } \\
\text { inhabitants] }\end{array}$ & $\begin{array}{c}\text { Subscribers } \\
\text { to mobile } \\
\text { telephone } \\
\text { services } \\
\text { [Per 100 } \\
\text { inhabitants] }\end{array}$ & $\begin{array}{c}\text { Total } \\
\text { telephone } \\
\text { subscribers } \\
\text { [Per 100 } \\
\text { inhabitants] }\end{array}$ & $\begin{array}{c}\text { Internet } \\
\text { users } \\
\text { [Per 100 }\end{array}$ \\
inhabitants] \\
\hline Spain & 43,16 & 2,28 & 0,29 & 26,64 & 93,91 & 137,07 & 34,85 \\
\hline Argentina & 22,38 & 2,38 & 0,03 & 7,72 & 34,76 & 57,14 & 13,17 \\
Bolivia & 6,97 & 0,09 & 0,00 & 2,12 & 20,07 & 27,04 & 3,90 \\
Colombia & 19,52 & 0,43 & 0,01 & 6,67 & 23,16 & 42,68 & 7,98 \\
Ecuador & 12,22 & 0,07 & 0,00 & 5,49 & 34,44 & 46,66 & 4,73 \\
Morocco & 4,38 & 0,01 & 0,00 & 2,07 & 31,23 & 35,60 & 11,71 \\
Pakistan & 2,96 & 0,02 & 0,00 & --23 & 3,30 & 6,27 & 1,32 \\
Peru & 7,44 & 0,40 & 0,02 & 9,75 & 14,85 & 22,28 & 11,68 \\
Romania & 19,70 & 0,22 & 0,02 & 11,00 & 45,85 & 65,55 & 20,20 \\
Senegal & 2,21 & 0,01 & 0,00 & 2,34 & 9,94 & 7,77 & 4,66 \\
China & 23,79 & 0,01 & 0,01 & 4,03 & 25,49 & 49,29 & 7,16 \\
\hline
\end{tabular}

Source: Data from the International Telecommunication Union-ITU

The penetration of ICTs in developing countries has a direct impact in the decreasing of costs of international communications. Since 2001 , the decreasing tendency of prices has accelerated as it is shown in Table 2. 
Table 2. Annual prices decline all over the world $1991-2005$

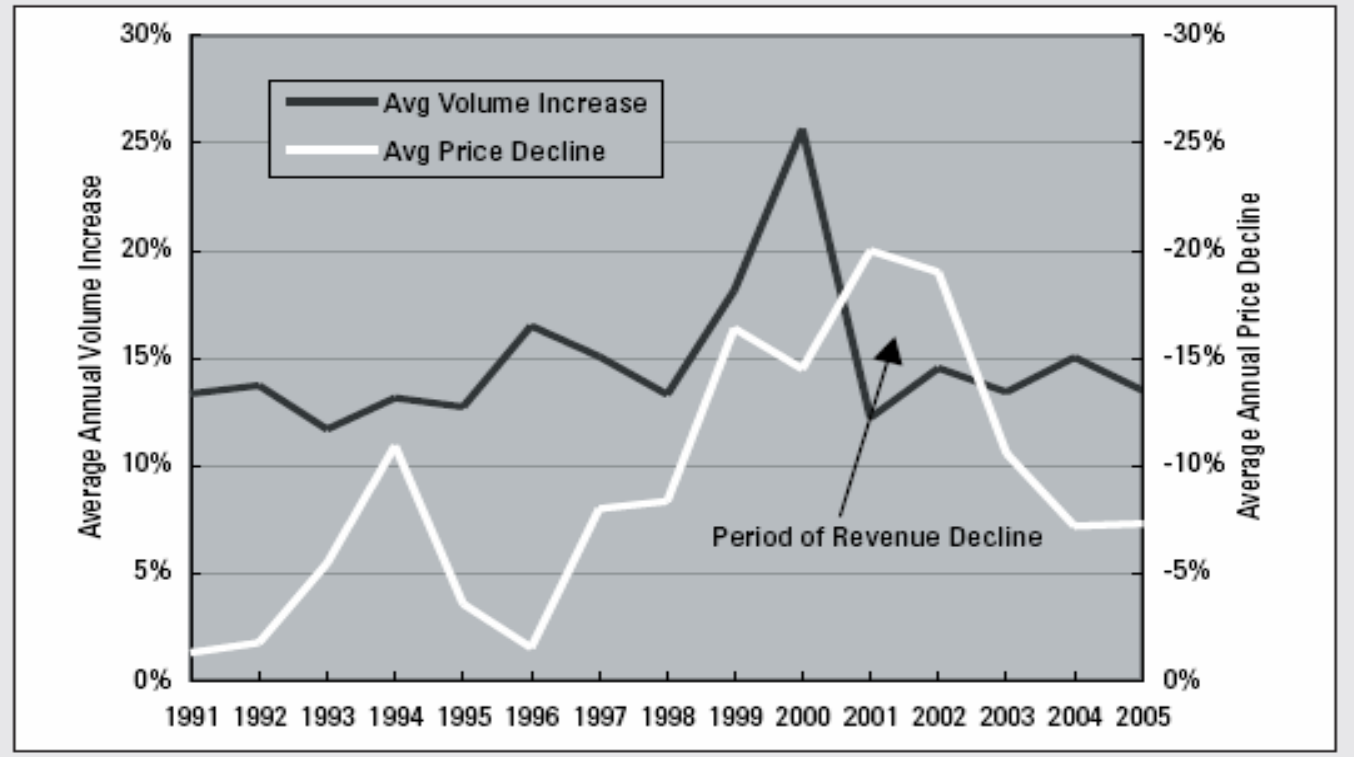

Notes: Data reflect both switched and VolP volumes. Periods where volume increases outpace average price declines mark a period of revenue growth. When price declines outpace volume increase, revenue declines.

Source: TeleGeography research

(1) PriMetrica, Inc. 2006

Source: Executive Summary 2006. Telegeography

As a result of decreasing costs, the traffic of international communications has unexpectedly grown in recent years. But what is more interesting for us is that developing countries -some of them are sending migrant countries too- are the fastest growing markets in switched international communication traffic as is shown in the next table.

Table 3. Ten Fastest Growing Markets in switched international communication traffic $2000-2005$

\begin{tabular}{|lcccc|}
\hline Country & Minutes (m) 2000 & Minutes (m) 2005 & Change 2000-2005 & Mobile Growth \\
\hline Nigeria & 66.0 & 530.0 & $703 \%$ & $61,857 \%$ \\
Ecuador & 55.5 & 291.5 & $425 \%$ & $1,178 \%$ \\
India & 527.1 & $2,295.0$ & $335 \%$ & $2,344 \%$ \\
Pakistan & 98.6 & 405.1 & $311 \%$ & $5,473 \%$ \\
Kuwait & 158.7 & 530.3 & $234 \%$ & $284 \%$ \\
\hline El Salvador & 128.0 & 409.0 & $220 \%$ & $211 \%$ \\
United Arab Emirates & $1,123.6$ & $3,346.4$ & $198 \%$ & $215 \%$ \\
Bolivia & 27.2 & 80.1 & $195 \%$ & $316 \%$ \\
Senegal & 50.0 & 147.2 & $194 \%$ & $724 \%$ \\
Venezuela & 239.0 & 695.5 & $191 \%$ & $131 \%$ \\
\hline
\end{tabular}

Notes: Data are for switched traffic only.

Sourca. Talofionarantwu rasoarch 
The penetration of ICT in origin countries and the decreasing costs of international communication make information more accessible to migrants than ever before. The greater accessibility of information is translated into a new information transmission between origin and destination countries. But, are these questions explored in the literature?

\subsection{Moving in the Information Age}

Although previous research describes contemporary migration, have the IS transformations been included in the description of contemporary migration? It is in this sense that we seek to contribute to this innovative field of research, hoping to push other scholars to address this question.

Among scholars that address the main features of contemporary international migration, it is possible to highlight some issues, that if do not focus on IS transformations, deal with four highly related questions to this paradigm. First, the great mobility that characterizes contemporary migration flows (Castles and Miller, 2003); and second, the great contradiction between the increasing mobility driven by globalization and the tendency to adopt restrictive policy controls at national borders (Cornelius et al., 1994; Hollifield, 2004). These two factors describe the framework in which this paper sets the study of contemporary migration.

Third, the increasing significance of new information and communication tools both at origin and destination countries (Panagakos and Horst, 2006; Vertovec, 2004) and fourth, the increase in migrant's agency as "they [migrants] seek to achieve better outcomes for themselves, their families and their communities by actively shaping the migratory process" (Castles, 2004b: 860). Both questions are central in order to understand changes in the capacity to process information in current migration contexts.

Present in all these contributions are two general tendencies that can help us to understand the scope of transformations -related to the role of information - that migrant flows may be experiencing. We refer to the global dimension of contemporary migration, and to the institutionalization of migration and the consequent autonomy of this process.

First, the global dimension of contemporary migration is well developed by Castles and Miller (2003). As these authors state, one of the main characteristics of current migration is its globalization. There is a new set of rules facilitating movement from one place to another, faster and cheaper than ever before. Globalization affects migration flows in several ways by incorporating new destinations, new transit countries for migration, and a tendency to circular migration, amongst others. Closer to the Information Society approach, Castles highlights that "globalization also creates strong cultural pressures for mobility. The global media projects idealized images of First World life-styles into the poorest villages. Electronic communications also facilitate the dissemination of knowledge of migration routes and work opportunities. Long-distance travel has become cheaper and more accessible" (2004a:211).

Second, contemporary migration flows have gained autonomy in recent decades, becoming more independent of the institutions that manage international migration (Guilmoto and Sandron, 2001). This autonomy fits well with the flexibility of communications and higher capacity of interactions offered by the Information Age. Thus, the tendency of international migration to be autonomous from the traditional manager of migrant flows -the Nation State- is compiled by the concept of "institutionalisation of migration". Guilmoto and Sandron (2001) adopted this concept to reflect the transformation of migration flows to "an apparently quasi-autonomous system, with rules and 
norms, allowing specific individuals and organisations to attain their objectives" (Guilmoto and Sandron 2001: 144). One of the consequences of the institutionalization of migration can be seen in "a substantial reduction in the coordination and information costs -changes in the information transmission-, notably because they [rules and norms in the migration process] restrict behaviours to a limited number from among the possible choices" (Guilmoto and Sandron 2001: $145)^{2}$. Migrants could become empowered to make more informed decisions if they have access to information and communication resources providing accurate information, whilst they could rely on well-consolidated information sources.

Thus, the scenario where potential migrants decide to migrate, when and where, seems to change in comparison to previous phases of migration. In that context, delimited by the globalization of migration and the institutionalization of the process, the capacity for processing information should be reconsidered. The next section will focus on the changes that information processing is experiencing in contemporary migration contexts.

\section{Changes in the information transmission}

In migration contexts, information plays a crucial role. For Tilly (1978), information providing was one of the main elements responsible for migration chains to new migrants thereby playing a determinant role in European migration history. The migration chain has contributed to a decrease in the high cost of information about opportunities for employment in the destination country (Tilly 1978:56). Information and communication has always flowed between origin and receiving countries. However, these flows today are channelled in unprecedented ways -faster and cheaper than ever before - as a result of information and communication technologies.

The global dimension of contemporary migration strengthened by improvements of information and communication technologies is shaping the capacity of processing information in migrant contexts. As it has been shown, today, information processing is defined by the information sources available and the decreasing costs of international communication. Those transformations may have an unexpected impact on the concept of distance, traditionally deterring the decision to migrate, or the uncertainty, associated with migration contexts, - both concepts are central to the decision to migrate.

So, the capacity of processing information will be shaped by the changes in the impact of distance and uncertainty in the decision to migrate. In order to address this question, we will elaborate the traditional concept of distance, and the concept of uncertainty in contemporary migration contexts, and how they may be currently changing.

\footnotetext{
${ }^{2}$ Related to the 'institutionalization of migration'

"...the choice [of migrants] must take into consideration a set of conventions, rules, norms and value systems that are specifics of each society and constitute the 'institutional' context of the migration process" (Guilmoto and Sandron, 2001: 135). The institutional framework "seeks to provide a context for transactions (in defining their modalities, in guaranteeing them, and in perpetuating them) in an environment marked by uncertainty" (Guilmoto and Sandron, 2001: 142)
} 


\subsection{The distance factor}

Traditionally, distance has been seen as a deterrence factor to migrate as it is associated with high cost of access to information and the low availability of sources (Allen and Curtis Eaton, 2005; O'Connell, 1997; Poot, 1996; Maier, 1990). The relationship was clear: the more distant the destination, the less accessible information. Under these conditions, potential migrants opted to move to closer destinations. But this scenario may be changing as a result of the IS transformations and the possibility of getting information at any time and from any place. Considering that international costs of communication have decreased -as data show-, the statement defending that "greater distance implies higher information costs; higher costs mean less information; less information deters migration" (Allen and Curtis Eaton, 2005: 1) should be revised. So, the impact on distance in contemporary migration contexts may be blurring. If in contemporary migration contexts, the availability of more information, more cheaply, does not depend on distance, people could be migrating to more distant places as they have access to wider information sources. The first hypothesis summarises this idea.

$\mathrm{H} 1$ - If cost of international communication is decreasing, migrants could have greater access to wider information sources

Migrants can take the decision to migrate with more information. The consequences of that new scenario are unexpected and need to be addressed.

But does having access to wider information sources translate into being well informed? Migrants could take better decisions about routes, destinations, conditions and when to depart. The more availability of information does not necessarily mean having better information. As a Senegalese guy explained, many Senegalese immigrants believe that the Canary Islands are much closer and that the trip may take three days, and not three weeks as it really does ${ }^{3}$. As a result, wider availability of information sources is not a guarantee of information quality, nor does it reduce the uncertainty remaining in migration contexts. Those sources could contain irrelevant or confusing information for migrants. This statement moves us to deepen our research by proposing a second hypothesis.

$\mathrm{H} 2$ - Having access to wider information sources, does not mean that migrants are better informed

Lower costs of communication may facilitate more information, but do not necessarily mean greater access to better information sources. The variety of information sources could drive potential migrants to situations of over information or false expectations. Some immigrants interviewed in Catalonia in January 2007 confirmed the spreading of rumours or the false expectations among potential migrants in origin countries ${ }^{4}$.

I heard that in Spain, there are more possibilities and it is easier to get papers. I almost didn't have any information about Spain, like the majority of people in my country. You have to come to Spain to realise the reality of the situation.

$\mathrm{P}$, from Togo

\footnotetext{
${ }^{3}$ Interview with a Senegalese immigrant who took a cayuco to the Canary Islands but he did not get to Spanish territory. He was deported to Senegal from Morocco. February 2008.

${ }^{4}$ In January 2007, the Research Programme run 18 interviews with migrants from different country regions: Sub-Saharan and North Africa; Asia; and South America. All of them were settled in Catalonia.
} 
Generally, us Africans don't speak about what really happens to us in Europe. The work that people do are embarrassing in Africa: for example cleaning. I can't say to people in Africa that I am cleaning the streets in Spain. People with diplomas who are doing cleaning work here, is badly seen in Africa. You could give false information but what really happens you can't communicate to friends there.

$\mathrm{P}$, from Togo

... pure information and the truth do not arrive. Well, what I'm saying is, how people live here, how Algerians, sub-sharan African, Moroccans, Tunisians... people think that everyone that comes to live here lives well, but there is also the other side as well where we suffer a lot. As well as the nostalgia, sometimes you feel a bit of racism.. These are all things that don't arrive there.

$\mathrm{Y}$, from Algeria

There are Senegalese that think that there aren't any poor Spanish. People think that everything is easy.

$\mathrm{N}$, from Senegal

Being better informed does not only depend on having access to wider information sources availability of information-. It also depends on the quality and usefulness of that information. Although the decreasing cost of international communication and the availability of wider information sources are spreading in migrant contexts, uncertainty is still present. That misinformation is evidenced by false expectations and rumours that remain in migration contexts. Representatives of international organizations in Bolivia for example agree that in order to better manage migration flows it is crucial to research what kind of information is flowing among migration networks and what are the best channels to inform potential migrants. ${ }^{5}$

But, what elements could make information clearer to migrants reducing uncertainty of migration?

\subsection{The uncertainty}

Although distance as a deterrent on migration has become blurred, uncertainty is still present in migration contexts in some cases conditioning the decision to migrate (Guilmoto and Sandron, 2001; Poot, 1996). ${ }^{6}$ Along these lines, O'Connell (1997) states that uncertainty about social and economic conditions that migrants will encounter in receiving countries clearly influence the decision of potential migrants. Thus, does having more capacity to process information reduce uncertainty in migration contexts? Or, on the contrary, does having access to wider information sources mean the introduction of false expectations and increasing uncertainty?

This question is still to be resolved in the literature on migration. However, some scholars such as Poot (1996), Guilmoto and Sandron (2001), and Koser and Pinkerton (2002) provide some useful reflections in order to address this question. On the basis of their reflections, we propose four requisites to reduce uncertainty: comprehensive, relevant, trusted, and updated information.

\footnotetext{
${ }^{5}$ Interviews with Ivan Prudencio, UNFPA - Bolivia, and Walter Arce, IOM - Bolivia January 2008.

6 "Most of the origin countries of migration are characterised by conditions of uncertainty and high costs of information" (Guilmoto and Sandron, 2001: 136). Parallel to the cost, "...potential migrants must take into account the uncertainty associated with wages, prices and other conditions in future years" (Poot, 1996: 60)
} 
First, information provided to migrants is often so complex that they have to turn to information agents who translate that information into a comprehensive language (Poot, 1996). The clearest example of complex information is related to legal permits and migration regulation, provided by official institutions. That complexity of language provokes misinformation amongst most migrants. Only high skilled migrants are able to understand the more complex information (Poot, 1996). Thus, what happens as regards low skilled migrants? Those migrants turn to the migration industry, or migration networks to get assistance as regards these questions, as the individual cost of becoming informed still remains high. So, having more available information does not translate into being better informed.

Second, in some other cases, migrants have difficulties in order to get the information they need as the sources they consult do not provide the relevant information for migration. By relevant information, we refer to information about destination, investment in terms of the cost of the voyage and establishing oneself in the new location, possibilities for staying, difficulties of finding employment, possibilities of maintaining links with the region of origin, amongst others (Guilmoto and Sandron, 2001). That is the reason why some migrants turn to specific information agents that are more aware of what kind of information migrants need (Guilmoto and Sandron, 2001). Among those agents we can specify the migration industry, migration networks, and even human smugglers.

Third, in migration contexts, uncertainty could only be reduced if migrants had access both to updated and trusted sources. The problem is complex as the more trusted sources offer out of date information; even if migrants perceive that it is updated. Although migrants have more capacity for processing information, they are still reluctant to consult those sources of information traditionally non trusted by them. Non traditionally trusted sources such as official institutions, are those that can provide the most updated information. On the contrary, traditionally trusted sources such as migration networks do not have the capacity to provide updated information (Koser and Pinkerton, 2002). They state that "information disseminated directly by formal institutions is unlikely to be trusted, the media is probably not sufficiently widespread or accessible in countries of origin, and friends and family will be unlikely to be informed about policy approaches" (Koser and Pinkerton, 2002:2). Here, it appears a third and main hypothesis

H3 - Without comprehensive, relevant, trusted and updated information, uncertainty could remain in migration contexts

This section has shown that changes in information transmission could be redefining the concept of distance as a deterrence factor, offering migrants access to wider information sources which could reduce uncertainty. However, being better informed requires relevant, updated, comrpehensive, and trusted information sources.

Those requisites, comprehensive, relevant, trusted, and updated determine the quality of information provided to migrants, on which they will base their expectations and decisions. Satisfying the four requisites could facilitate migrants to take more informed decisions and migrate to more distant places. However, these hypothesis need to be demonstrated by developing empirical work and gathering data from migrants experiences both at origin and destination contexts. 
As it will be shown in next section, the achievement of those factors will depend on the agent whom provides each piece of information. It will also demonstrate that a better coordination between information agents becomes crucial in the fight against overinformation, rumourology, false expectations, and contradictory information.

\section{The information agents in contemporary migration}

The aim of this section is to analyze to what extent information agents in migration contexts incorporate in their proceedings the four conditions described above: comprehensive, relevant, trusted, and updated information. By doing this, it will be possible to identify variations among different information agents and highlight which of them best satisfy these requisites in helping migrants to make more informed decisions.

The concept of information agents in migration contexts refers to those actors that amass information that potential migrants need in order to migrate. The extent of information that potential migrants need includes travel expenses, best destinations, migration regulation, and accommodation, amongst others.

Among the basic information agents in migration contexts, literature on migration highlights the migration industry, migration networks, human smugglers, and official institutions as Figure 1 shows. The boundaries between each of these actors are difficult to establish as they share a common space of action -information providers - in most cases. However, we will try to define each one as a different actor showing its particularities. Migrant's agency will be mentioned separately as it is still an emerging actor and it is difficult to define its impact as an information agent. At the end of the section, we will address this issue.

Figure 1. Information agents in migration contexts

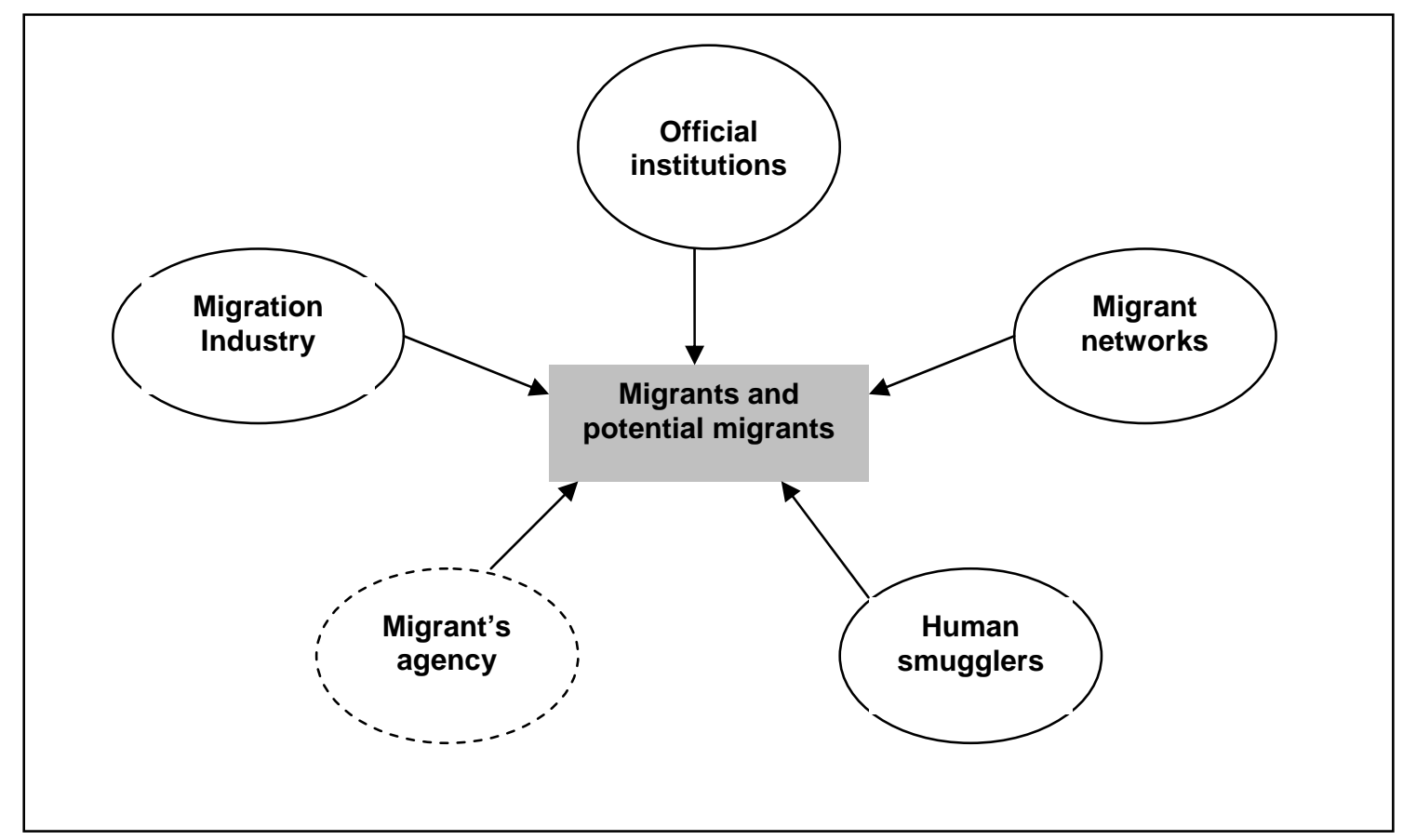


Each agent, following our argument, manages current migration flows by providing information, as a tool to migrate. According to this approach, depending on whether or not agents fulfil the requisites of information processing, they will be better positioned against others as sources of information to migrants.

These actors and their position in the map of information providers should be taken into consideration in the designing of better measures for managing migration in order to achieve more realistic migration policies. If this doesn't occur, these agents will continue to act parallel to the official institutions diversifying the information they provide to migrants, thereby hindering the management of migration flows. The question therefore becomes how to take advantage of the diversity of information agents by coordinating efforts, and not isolating each of one.

In the following pages, we will describe in detail each actor and the way they satisfy some but not all the four requisites of information -comprehensive, relevant, trusted, and updated-. As a first step to support the description, table 4 shows the structure to analyze each information agent and evaluate how it has adapted to information processing in the contemporary migration context.

Table 4. Basic information issues for contemporary migration

\begin{tabular}{|l|cccc|}
\cline { 2 - 5 } \multicolumn{1}{l|}{} & $\begin{array}{c}\text { Migration } \\
\text { industry }\end{array}$ & $\begin{array}{c}\text { Migration } \\
\text { networks }\end{array}$ & $\begin{array}{c}\text { Human } \\
\text { smugglers }\end{array}$ & $\begin{array}{c}\text { Official } \\
\text { institutions }\end{array}$ \\
\hline $\begin{array}{l}\text { Comprehensive } \\
\text { language } \\
\text { Relevant information }\end{array}$ & Comprehensive & Comprehensive & Comprehensive & Incomprehensive \\
Trusted sources & Relevant & Relevant & Relevant & Partially relevant \\
updated information & Updated & Trusted & "Trusted" & Non trusted \\
& & Out of Date & Updated & Updated \\
\hline
\end{tabular}

\subsection{Migration industry}

The concept of 'migration industry' refers to all actors who intervene in the migration process. Based on that definition, we could include migration networks, human smugglers, intermediaries and even official institutions. However, we will refer to the migration industry following Castles' (2004b:209, 2000:272) as the sum of different actors such as "travel agents, lawyers, bankers, labour recruiters, brokers, interpreters and housing agents among others". Each of these actors share two main characteristics: they are private actors and act in a legal arena. The role of the migration industry is to provide assistance to migrants in the migration process (Poot, 1996; Guilmoto and Sandron, 2001). Migrants turn to the migration industry searching for relevant and updated information.

The migration industry tends to offer a comprehensive language as they are concerned that migration regulation is complex and difficult to understand. They act as 'translators' of complex information addressed to migrants (Poot, 1996). This is illustrated in many websites ${ }^{7}$. For instance, in the website www.mequieroir.com, there is a special emphasis on their services

\footnotetext{
${ }^{7}$ Here are some examples from the Spanish context.

How to Migrate - http://www.how2immigrate.net/; Work Permit - http://www.workpermit.com/; Migration Expert - http://www.migrationexpert.com/; and, Visa Centre -
} 
It responds to the need for information that is on-line, organised, ordered, easy to access, comprehensive, and is only one place, dealing with those procedures and requirements in order to undertake a life project in a foreign county with emphasis on migratory opportunities, of study and work $^{8}$.

By taking advantage of new opportunities of information and communication that the IS offers, the migration industry is spreading their activities by the Internet. Most of those agents offer their services through web pages that can be consulted from any place in the world. These web pages offer information about relevant items for migrants as visa permits to enter each country, working and housing conditions in the destination countries, even the possibility to send them a "free initial immigration assessment" in order to check whether or not individuals are eligible candidates to apply $^{9}$.

Behind these web pages there are organisations operating across the world. As they are wellstructured and consolidated entities, they can provide updated information, being trusted sources for migrants (Koser and Pinkerton, 2002). They count on the support of companies with interest in the benefits of immigration -communication companies, banks, remittance companies, even airline companies-. The activities of the migration industry supplements the shortcomings of the migration networks (Guilmoto and Sandron, 2001), as the latter can not offer updated information and does not count on the support of private entities, ie. business.

The migration industry can however also become a source of rumourology or false information. The example of visa requirements for Bolivians entering Spain, illustrates the non-desirable effects of access to wider information sources. Some months before the visa requirement came into force, some travel agencies took advantage of the situation by offering special products to migrate to Spain before $1^{\text {st }}$ April 2007. The most extreme case was the publicity designed by LAB -one of the main Bolivian airlines - spread by Bolivian radio and TV in which the slogan promised to return back half of the total amount of the flight ticket to those Bolivians who were not able to enter Spain (La Vanguardia, 2007).

Along similar lines, several travel agencies emerged in order to take advantage of the Bolivian migratory boom from when the new regulation was announced in September 2006 until the measure became effective in April 2007. Those agencies -some of them clandestine- offered closed packages for moving to Spain including passport, invitation letter, hotel booking, travel insurance, international vaccine, and flight tickets, for the amount of \$US 2.600 (El Deber, 2007). This effect was reported by the Bolivia-Spain Association for Cooperation -ACOBE- by stating that most of these agencies closed once they had sold all the passages for flights to Spain (La Vanguardia, 2007). Among their services, other agencies offered training courses addressed to potential migrants to show them how to dress, how to speak and behave during the trip and once

http://www.visacentre.co.uk/; Euroresidentes - http://www.euroresidentes.com/; Con papeles http://www.conpapeles.com/; Extranjeros sin papeles - http://www.extranjerossinpapeles.com/; Todo Legal - http://www.e-todolegal.com/; Autónomos Inmigrantes http://www.autonomosinmigrantes.com/index.htm; A Emigrar - http://www.aemigrar.com/index.php; Just Landed - http://www.justlanded.com/; o, Emigración Legal - http://www.emigracionlegal.com/

${ }^{8}$ Me quiero ir - http://www.mequieroir.com/legal/

${ }^{9}$ Most of these web pages offer assistance to migrate to destination countries with a point-based system. The point-based system is adopted by countries as Canada, Australia, and New Zealand as a mechanism to accept those migrants that fulfil the requisites established by migration regulation. This system is oriented to promote the migration of high skilled workers. 
they arrive to the police control in Spain ${ }^{10}$. The Ombudsman of Santa Cruz, in Bolivia, warns of the lack of public institutions controlling the activities of these agencies.

\subsection{Migration networks}

Migration networks are still one of the most important information providers for migrants. They are the oldest organisation managing migration in such a way that they have a well-consolidated structure widely extended among migrant communities, "reducing the individual cost of getting information and providing better quality information" (Poot 1996:65; Massey, 1990). Their position enables them to provide relevant information in a comprehensive language -they were migrants too- for potential migrants who "will have recourse to networks at different stages of their progress: support for the migration project, identification of destinations and desirable periods, advance of the costs of moving, accompaniment during the voyage, passage across borders, lodging and establishment in the labour market in the destination, material and non-material exchanges with the village of origin" (Guilmoto and Sandron, 2001:149).

Contrary to other information sources, migration networks are perceived by migrants and potential migrants "to provide the most relevant information and unlike other sources, are trusted not to distort information" (Koser and Pinkerton, 2002:1). Migration networks, thus, contribute to the collection and dissemination of that information (Dayton Johnson et al., 2007). Their long tradition makes them "the most trusted information source" (Koser and Pinkerton, 2002:2). Migration networks are present in most destination countries and the information they provide is based on their own experiences of being the first migrants to arrive.

However, the disadvantage of migration networks is that they do not provide updated information. First, the information they provide is obtained from experiences of migrants or secondary sources. Although it is perceived that the information they provide is up-to-date, they can not take into consideration recent changes in migration regulation (Koser and Pinkerton, 2002). Second, as information provided by migration networks is mainly based on personal experiences, it can also be very subjective. As interviews with some migrants show, most give an image of success when they speak to friends and family in the country of origin, they do not want to show their failure as the following quote shows:

So, the people who have been here for two years, and come to the town with a massive car, with money, so the people there it affects them a little.. To go back with a 'mercedes'.. and this.. to me.. I am completely against it, when I went back, well, I went back normal, without car without anything... many people don't tell the truth. This is why it doesn't arrive. Don't cross the Mediterranean.

$\mathrm{Y}$, from Algeria

Well, with the information, and you see also other Senegaleses that have emigrated to other countries, like Spain and go back to Senegal to show that it is easy to have a life here. They don't show the reality.. This is what I say to you, you see the tele and Senegalese that have emigrated to France and Spain and when they return flash their money. They want to believe it and think that it is easy.

$\mathrm{N}$, from Senegal

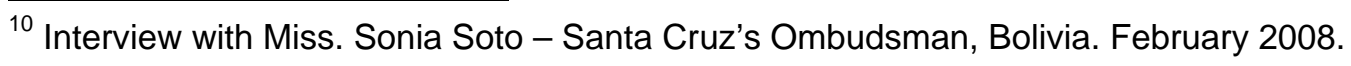




\subsection{Human smugglers}

Human smuggling can be defined as "every act whereby an immigrant is assisted in crossing international borders whereby this crossing is not endorsed by the government of the receiving state, neither implicitly nor explicitly" (Liempt and Doomernik, 2006:166). It could be argued that they take advantage of the widening gap between policy goals and outcomes by increasing their space of action (Castles, 2004a; Cornelius, 2001; Massey, 1999).

Human smugglers provide relevant information in a comprehensive language reducing the individual cost of becoming informed. Smugglers gather updated information in important issues such as whether access is easy in terms of border control and deportation policies, whether it is profitable to take someone there (and not to another place) as they are themselves connected to a network in that specific country so that they can rely on knowledge and expertise (Liempt and Doomernik, 2006).

They also gather information about countries which are the easiest targets (in terms of border controls or migrant regulation), which is the best way of exploiting asylum procedures and knowledge of which routes and means of transport are the most reliable (Salt and Steiner, 1997). The information provided by smugglers covers the relevant stages of the migration process, "assisting migrants in the movement in route; and supporting their insertion and integration into labour markets and host societies" (Salt and Steiner, 1997:467). They provide these relevant issues in a comprehensive language for their clients.

Human smugglers base their activities on accurate and updated information that helps them to decide the best destinations, the easiest to get to, the less controlled, and the best time to go. Their well-consolidated structure facilitates information gathering and the accumulation of information that determine the survival of these organizations. The components of those structures are individuals who manage the flow of information and who have access to well organized and perhaps centralized communications systems using state-of-the-art technology (Salt and Steiner, 1997).

Smugglers are trusted sources for migrants who usually do not have any other means to obtain information. They are trusted by necessity, as targeted clients of human smugglers are migrants who do not have any ethnic network in the destination country on which they could rely or receive help to find accommodation and work or to get practical information on their arrival. These migrants could contact human smugglers as providers of basic information in order to settle in the country of destination (Liempt and Doomernik, 2006). Thus, their trust is based more on necessity than on confidence in migration networks or the migration industry.

\subsection{The official institutional framework}

Official institutions amass the most updated information, as they are embedded in the decisionmaking process of migration policies, compiling the main components of migration regulation that could be of interest for migrants -legal permits, family reunification, requisites of entrance, acquisition of nationality-. However, the role of institutions as information providers is faced by some crucial difficulties. 
On the one hand, official institutions are the least trusted sources amongst migrants limiting the usefulness of such updated information (Koser and Pinkerton, 2002). This lack of trust is not based on the idea that official institutions could be interested in providing misinformation in order to deter migration, but it is related to the lack of trust of any formal institution (Koser and Pinkerton, 2002).

Despite this some authors (Poot, 1996) warn that information provided by these institutions is so complex that it can become incomprehensible. It is only available to highly skilled migrants, while low skilled immigrants are not able to understand and use the complex information provided by formal institutions (Poot, 1996). This situation is related to the nature of information channels, formal or informal whilst official institutions clearly belong to the first category. While skilled migrants can turn to both formal and informal sources, low skilled workers tend to rely only on the informal channels of their own networks. As Poot states, "migrant network [becomes for unskilled migrants] an important source of information both in providing the information which motivates the decision to move and for the actual local job search once the move has been made" (Poot, 1996:66).

Not only are official institutions non trusted sources, however they also lack the provision of relevant information. Several official sources only provide information about migration regulation, and do not offer information about other relevant issues too - for example official services to find accommodation, or the public institutions which might help to find a job.

In the absence of an efficient official system of information (satisfying the requisites of comprehensive, relevant, trusted, and updated), migrants turn to parallel institutions or providers as those we listed above -the migration industry, migration networks, or human smugglers - in order to get this information (Guilmoto and Sandron, 2001).

However, in recent years some initiatives are incorporating for first time the centrality of information into their policy measures to manage contemporary migration. The majority of them are run with support of the International Organization for Migration (IOM). Some examples are the information dissemination campaigns in Zimbabwe, India, Albania, Ukraine, Bulgaria, Czech Republic, among others.

Two of the most innovative good practices are the Canadian Initiative for promoting immigrant integration before departure and the Spanish campaign addressed to Senegal.

First, the goal of the Canadian Immigration Integration Project is to facilitate the integration of those migrants who are trained and ready to work in their fields of expertise into the Canadian workforce more quickly ${ }^{11}$. The aim is to provide accurate assistance through helping skilled workers prepare for integration into the Canadian labour market while completing the immigration process in their country of origin. The crucial factor to achieve these goals is to provide relevant information about the destination country in order to enable migrants to make the most appropriate choices once having arrived to Canada. Thereby, facilitating their integration. As a pilot project, the implementation is being applied in three origin countries: China, India, and the Philippines.

Second, the Spanish campaign against irregular immigration seeks to provide accurate information to irregular emigration candidates ${ }^{12}$. The goal of the campaign is to prevent the dangers and

\footnotetext{
${ }^{11}$ Canadian Immigration Integration Project - http://ciip.accc.ca/

${ }^{12}$ Spanish Campaign against irregular migration from Africa http://www.tt.mtas.es/periodico/inmigracion/200709/INM20070918.htm
} 
uselessness of irregular migration and to make youth aware of their involvement in the development of their own country. The campaign is implemented in Senegal as a measure to deter potential migrants from irregular migration. The initiative is funded by the Spanish government and the Organisation for International Migration (OIM), with the support of the European programme AENEAS. The message is being spread by TV, radio, and the press, but activities will be developed to make people aware of the phenomena in collaboration with non governmental organisations and influential figures. Both initiatives put information diffusion at the core of the project. However, it will be necessary to evaluate their effectiveness and impact in order to design further appropriate measures.

In summary, a first step to improve international migration management by better incorporating the role of information resources is considered necessary for a better official information system. This information system should deal with issues of comprehensiveness, availability, relevance, and updated information, by coordinating efforts with the most trusted sources such as migration networks. It is also very important to think in terms of the dynamism of migration, and disseminating information both in origin and destination countries addressed to all migrants - both low and highly skilled. This strategy should take advantage of the information and communication opportunities existing in contemporary societies, both at origin and at destination.

Although absent from our analysis, it is worth mentioning that a new information agent is appearing and gaining power in recent years. We refer to the migrant's agency. Despite the fact that it is difficult to describe their impact as an information agent, we consider that their figure should be taken into consideration in future research. Migrant's agency refers to the gaining in autonomy of migrants, "being not just isolated individuals who react to market stimuli and bureaucratic rules, but social beings who seek to achieve better outcomes for themselves, their families, and their communities through actively shaping the migratory process" (Castles 2004a:209). As Poot states,

...it has become clear that each potential migrant [...] becomes a new opportunity seeker whose search process is guided by formal and informal information acquired through the advanced communication sector of through informal contact networks. Consequently, the size, composition and direction of international migration flows are to a significant extent contingent on the information transfer regarding the benefits and disadvantages of potential host countries (including information on regulatory regimes regarding contract migration, permanent settlement and asylum) (Poot, 1996: 70)

In the Information Society, it is possible that as migrants become empowered by the availability of communication and information tools, their capacity increases to better process information. These tools may offer migrants more possibilities than ever to organize themselves in the migration process and to keep in contact with their networks, independent of where they are placed. Today, in the Information Age, migrants may not depend as much as in previous phases, on the intermediation of 'migration industry' or human smugglers. They could, by themselves use those 
means of communication to get in contact with official services of recruitment, thereby reducing dependency on intermediaries. As a result of these gains in autonomy, capable migrants manage new information and communication tools and could therefore become new information agents parallel to 'migration industry', human smugglers or official institutions, thus bypassing the dependency on migration networks.

Some examples of migrant's autonomy can be seen in the appearance of web pages designed and managed by migrants providing information and assistance to potential migrants or providing information about their origin countries - for example, newspapers on-line-. Among these portals we should also include migrant forums or blogs in which migrants share their opinions and resolve doubts about the migration experience. Different from migration industry portals, these web pages are run by migrants who have first hand knowledge of what migration means. Among those initiatives we highlight the commonly named ethnic media as Canal Latino http://www.canallatino.tv/; Sí se puede - http://www.sisepuede.es/; Infolatino http://www.infolatino.info/; and, some blogs as Foro Hispano http://foros.hispavista.com/inmigracion/; Migrantes en Línea - http://www.migrantesenlinea.org/; Emigra web - www.emigraweb.net; Colombianos en España - www.colombianosenespana.com; or Red Peruana - www.redperuana.com. These kind of forums also exist in other destination countries as the web page Philippines in Australia - http://www.philippines.com.aul.

Turning to the goal of this section, we have seen how the different information agents in the migration context incorporate the requisites to better inform potential migrants (comprehensiveness, relevance, trust, and update). From this analysis, we highlight some relevant reflections to follow-up in future research.

First, and as is shown, the migration industry and human smugglers are efficient information agents as they provide relevant and updated information in a comprehensive language, whilst they are also trusted sources. However, the role of both agents is explained by the necessity of migrants to get information, as they cannot turn to other agents -they do not belong to any migration network or they are not able to understand information provided by official institutions-. The information provided by both agents may lead to contradictory situations and unprotection for migrants. First, the migration industry can orient migrants in the process of legal permit procedures, but what happens once migrants arrive to the destination country? Should this role of assistance not belong to official institutions? Second, the assistance and information provided by human smugglers could guide migrants even once they arrive to the destination country, but those migrants will remain in illegal situations. Thus, despite the fact that human smugglers have to be considered as an information agent they need to be fought against as an illegal actor if we seek to better manage contemporary migration flows, thereby reducing the suffering of migrants travelling in irregular conditions.

Second, a consideration of the dichotomy between trusted and updated sources could in fact lead to a recommendation as regards an alliance between two of the main information agents: migration networks and official institutions. While the former is trusted by the migrant community both at origin and destination countries, the latter can provide the most updated information and offer public assistance to migrants, as it has been shown in the subsection dedicated to official institutions. However, this alliance is currently inexistent.

"Migration networks operate independently of government policies and often in spite of them" (Massey et al., 1998:61). The next step would be to analyze how this alliance could be made. 
Assuming that migration networks are the most trusted source and they provide relevant and comrpehensive information -as they are aware of what kind of information migrants need-, they could be allied to official institutions to provide consistent information responding to the necessities of migrants and satisfying the four factors of updated, comprehensive, relevant, and trusted information. By doing this, would it be possible to reduce the uncertainty remaining in migration contexts thereby combating misunderstandings or biased information?

Third, migrants' agency is appearing as a new information agent that seems to be absolutely immersed in the Information Society. Internet tools (webpages, forums, blogs, e-mail...) are used as the basic infrastructure to spread information and keep in contact from any place at any moment. Would this agency interact with migration networks and official institutions? If so, how would the map of information agents change?

Fourth, information agents still matter in any project to migrate. However, what is new is how information agents operate in the Information Age, as potential migrants have wider access to information sources and therefore increase their capacity to process information.

The interaction between information agents described here should be considered in the analysis of the information that migrants have before departure, during the trip, or once they arrive to the destination country. This dynamism must be taken into consideration.

\section{Concluding remarks}

Migrants could have more information to make informed decisions and to move to more distant places through the new opportunities that decreasing costs of international communication and the penetration of ICT in countries of origin offer. However, this paper also warns that having access to wider information sources does not necessarily mean being better informed. At this stage, access to information not only is important, but also the quality of that information.

To be better informed depends on the accomplishment of four basic factors: comprehensive, relevant and updated information provided by trusted sources. In the accomplishment of those factors the role of information providers is crucial. As we argue even the migration industry and human smugglers provide relevant, updated and comprehensive information, they are trusted by necessity -as their "clients" do not have any other option, they do not belong to any migration network or they are not able to understand what official institutions say-. This paper argues that increased co-operation of migration networks -most trusted sources and knowledge of the relevant items - and official institutions -most updated information - could fulfil existing gaps and correcting biased information, reducing the uncertainty that is still present among some migration contexts.

All of the agents described in section 3 provide information and contribute in different ways to maintain migration movements -as they provide a basic tool for migration: information. At this stage, there is a need for coordination between formal information agents in order to provide the same information to any migrant, solving questions as overinformation or contradictory information. As migrant interviews show, there are still some barriers preventing migrants from being well informed.

Through this paper, we seek to demonstrate that information processing is affecting the reality of contemporary migration through the intervention of information agents and that migration policies should consider more realistic measures to manage contemporary international migration. 
For passing from this theoretical approach to the empirical work, we propose to gather some data to check the main hypothesis posed in section 2: Without comprehensive, relevant, trusted and updated information, uncertainty could remain in migration contexts. This argument could be empirically tested by interviewing the main actors embedded in the more trusted and updated information provision in migration contexts: members of official institutions, members of migration networks; and potential migrants. Parallel to this work, it would be also necessary to analyse the information provided by information agents, for example a first step could be the analysis of those web pages mentioned in section 3 .

\section{Aknowledgements}

We would like to thank the Internet Interdisciplinary Institute (Universitat Oberta de Catalunya) and the Departament d'Innovació, Universitats i Empresa of the Generalitat of Catalonia (Catalan Government) for their financial support. 


\section{References}

ALLEN, J. and CURTIS EATON, B. (2005) "Incomplete Information and Migration. The Grass is Greener Across the Higher Fence", Journal of Regional Science, 45 : 1. Pp. 1-19

CASTELLS, M. (1996) The Information Age: Economy, Society, and Culture. Volume 1: The Rise of the Network Society. Oxford, and Malden, MA: Blackwell Publishers

CASTELLS, M., FERNÁNDEZ-ARDĖVOL, M., QIU, J. and SEY, A. (2007) Mobile Communication and Society. A Global Perspective. Cambridge, Massachusetts: The MIT Press

CASTLES, S. (2000) "International Migration at the Beginning of the Twenty-First Century. Global Trends and Issues", International Social Sciences Journal, 52:165. Pp. 269-281.

(2004a) "Why Migration Policies Fail", Ethnic and Racial Studies, 27:2. Pp. 205-227

(2004b) "The Factors that Make and Unmake Migration Policies", International Migration Review, 38:3. Pp. 852-884

CASTLES, S. and MILLER, M. (2003) The Age of Migration. International Population Movements in the Modern World. New York/London: The Guilford Press

CORNELIUS, W. (2001) "Death at the Border. Efficacy and Unintended Consequences of US Immigration Control Policy", Population and Development Review, 27:4. Pp. 661-685

CORNELIUS, W., et al. (1994) Controlling Immigration. A Global Perspective. Stanford: Stanford University Press

DAYTON JOHNSON, J., KATSELI, L., MANIATIS, G., MÜNZ, R., PAPADEMETRIOU, D. (2007) "Migration and Development. Partnerships for Mobility Management", in DAYTON JOHNSON, J. et al., Gaining from Migration. Towards a New Mobility System. OECD Publications - Development Centre

EL DEBER (2007) "Pasajeros acusaron a las agencias por paquetes caros", 30 de Marzo de 2007

EL PAIS (2006) "Andalucía acoge a un millar de muchachos magrebíes", 20 de Septiembre de 2006 (2007) "Un millar de inmigrantes bolivianos entran diariamente por el aeropuerto de Barajas", 4 de Enero de 2007

GUILMOTO, C. and SANDRON, F. (2001) "The Internal Dynamics of Migration Networks in Developing Countries", Population: An English Selection, 13:2. Pp.135-164

HELD, D., McGREW, A., GOLDBLATT, D. and PERRATON, J. (1999) Global Transformations. Cambridge: Polity Press.

HOLLIFIELD, J. (2004) "The Emerging Migration State", International Migration Review, 38:3. Pp. 885912

IOM-FOM (2005) "Managing migration. Interstate Cooperation at the Global Level", in Interstate Cooperation and Migration. Geneva: IOM

KOSER, K. and PINKERTON, C. (2002) The Social Networks of Asylum Seekers and the Dissemination of Information about Countries of Asylum. London: Home Office, Research Development and Statistics Directorate.

LA VANGUARDIA (2006) "Más de cien inmigrantes en seis pateras", 11 de Octubre de 2006 (2007) "Si le deportan, le devolvemos el 50\% del coste de su billete", 31 de Marzo de 2007

LIEMPT, I. and DOOMERNIK, J. (2006) "Migrant's Agency in the Smuggling Process. The Perspectives of Smuggled Migrants in the Netherlands", International Migration, 44: 4. Pp. 165190

MAIER, G. (1990) "The Economics of Information in the Context of Migration", in Johnson, J. and Salt, J. (Eds), Labour Migration. The Internal Geographical Mobility of Labour in the Developed World. London: David Fulton Publishers

MASSEY, D. (1990) "The Social and Economic Origins of Immigration", ANNALS, AAPSS: 510. Pp. 6072 
(1999) "International Migration at the Dawn of Twenty-First Century. The Role of the State", Population and Development Review, 25:2. Pp. 303-322

MASSEY, D. et al. (1998) Worlds in Motion. Understanding International Migration at the End of the Millennium. Oxford and New York : Oxford University Press

O'CONNELL, P. (1997) "Migration under Uncertainty. 'Try your Luck' or 'Wait and See', Journal of Regional Science, 37 : 2. Pp. 331-347

PANAGAKOS, A. and HORST, H. (2006) "Return to Cyberia. Technology and the Social Worlds of Transnational Migrants", Global Networks, 6:2. Pp. 109-124

POOT, J. (1996) "Information, communication and networks in international migration systems", The Annals of Regional Science, 30. Pp. 55-73

ROS, A. (2008) "Interconnected Immigrant in the Information Society". In Oiarzabal, P.J., Alonso, A.

(Eds) Digital Diasporas. Reno: University of Nevada Press

SALT, J. and STEIN, J. (1997) "Migration as a Business. The Case of Trafficking", International Migration, 35 : 4. Pp. 467-494

TELEGEOGRAPHY (2006) TeleGeography Executive Summary 2007

TILLY, C. (1978) "Migration in Modern European History". In McNeill, W. and Adams, R. (1978) Human Migration. Patterns and Policies. Indiana: Indiana University Press, Bloomington \& London. Chapter three, Pp.48 - 74.

VERTOVEC, S. (2004) "Cheap Calls. The Social Glue of Migrant Transnationalism", Global Networks, 4:2. pp. $219-224$ 